\title{
Seasonal photoreactivity of dissolved organic matter from lakes with contrasting humic content
}

\author{
Måns J. Lindell, H. Wilhelm Granéli, and Stefan Bertilsson
}

\begin{abstract}
We studied seasonal variability in photodegradation of dissolved organic carbon (DOC) resulting from artificial ultraviolet-A (UV-A) and UV-B irradiation. Water samples were taken approximately monthly from the surface layers of two oligotrophic lakes with contrasting humic content, situated in southern Sweden. Lake water was filtersterilized $(0.2 \mu \mathrm{m})$ and exposed to artificial UV radiation in quartz tubes. Potential DOC photodegradation, measured as a photoproduction of dissolved inorganic carbon (DIC) and oxalic, malonic, formic, and acetic acid in irradiated samples, was observed throughout the sampling period. In addition, exposure to UV radiation resulted in a decrease in DOC, absorbance, and humic substance fluorescence. The photoproduction of DIC and the low molecular weight (LMW) organic acids varied seasonally, being generally higher in winter and spring (December-May), while DOC appeared to become less photoreactive after the extensive exposure to solar radiation during summer. Production rates of both DIC and LMW organic acids were approximately eight times higher in the humic lake despite that the DOC concentration was only two times higher than in the clearwater lake. This is most probably due to the high input of allochthonous DOC and the resulting higher absorbance to DOC ratio in the humic system. Furthermore, the longer hydraulic residence time in the clearwater system could have resulted in an accumulation of residual DOC, recalcitrant to further photodegradation.
\end{abstract}

\begin{abstract}
Résumé : Nous avons étudié la variabilité saisonnière de la photodégradation du carbone organique dissous (COD) causée par le rayonnement artificiel UV-A et UV-B. Des échantillons d'eau ont été prélevés à intervalle d'un mois environ dans les couches superficielles de deux lacs oligotrophes à teneur humique différente situés dans le sud de la Suède. L'eau des lacs a été stérilisée par filtration $(0,2 \mu \mathrm{m})$ et exposée à un rayonnement UV artificiel dans des tubes à quartz. La photodégradation potentielle du COD, mesurée en termes de photoproduction de carbone inorganique dissous (CID) et d'acides oxalique, malonique, formique et acétique dans les échantillons irradiés, a été observée tout au long de la période d'échantillonnage. De plus, l'exposition au rayonnement UV a provoqué une baisse du COD, de l'absorbance et de la fluorescence des substances humiques. La photoproduction de CID et des acides organiques à faible poids moléculaire (FPM) variait selon la saison, et elle était généralement plus élevée en hiver et au printemps (déc. - mai), tandis que le COD semblait moins photoréactif après une longue exposition au rayonnement solaire pendant l'été. Les taux de production de CID et d'acides organiques (SPM) étaient environ 8 fois plus élevés dans le lac humique, malgré le fait que la concentration de COD y était seulement 2 fois plus élevée que dans le lac aux eaux claires; cela est très probablement dû à l'apport élevé de COD allochtone et aux rapports plus élevés de l'absorbance au COD qui en résultent dans le système humique. De plus, le temps de séjour hydraulique plus long dans le système aux eaux claires peut avoir provoqué une accumulation de COD résiduel, résistant à toute autre photodégradation.
\end{abstract}

[Traduit par la Rédaction]

\section{Introduction}

High molecular weight (HMW) organic molecules have previously been considered to have long turnover times in aquatic ecosystems compared with the rapidly utilized low

Received April 23, 1999. Accepted August 4, 1999.

$\mathrm{J} 15114$

M.J. Lindell and H.W. Granéli. ${ }^{1}$ Department of Ecology/Limnology, Lund University, S-223 62 Lund, Sweden.

S. Bertilsson. ${ }^{2}$ Department of Water and Environmental Studies, Linköping University, S-581 83 Linköping, Sweden.

${ }^{1}$ Author to whom all correspondence should be addressed. e-mail: wilhelm.graneli@limnol.lu.se

${ }^{2}$ Present address: Department of Civil and Environmental Engineering, The Ralph M. Parsons Laboratory, Massachusetts Institute of Technology, Cambridge, MA 02139, U.S.A. molecular weight (LMW) organic pool (Fenchel and Blackburn 1979; Chrost and Faust 1983). This view has recently been revised, since some HMW organic compounds exhibit turnover times comparable with those of biolabile LMW molecules (Tranvik 1990; Amon and Benner 1996).

Sunlight, and especially ultraviolet (UV) radiation (wavelength $<400 \mathrm{~nm}$ ), may play a significant role in the turnover and dynamics of dissolved organic carbon (DOC) in lakes. Photochemical reactions could affect DOC, both through complete oxidation into dissolved inorganic carbon (DIC) (Salonen and Vähätalo 1994; Miller and Zepp 1995; Granéli et al. 1996) and by transformation of large molecules into LMW organic substances, directly available for bacterioplankton utilization (reviewed by Moran and Zepp 1997). Consequently, photochemical reactions could partly explain supersaturation of $\mathrm{CO}_{2}$ in lakes and oceans (Cole et al. 1994) through either a direct abiotic oxidation of DOC into DIC or indirectly through increased respiration due to stimulated bacterial growth caused by the photochemical produc- 
tion of bacterial substrates (Lindell et al. 1995; Wetzel et al. 1995).

Many recent discussions on photooxidation are based on the assumption that DOC exhibits similar photosensitivity to solar radiation, independent of past light history (Valentine and Zepp 1993; Scully et al. 1996; Granéli et al. 1998). These studies demonstrate similarities in DOC photodegradability on a spatial scale but disregard the potential for changes on a temporal scale. The photodegradability of DOC by solar radiation may decrease with prolonged light exposure (Geller 1986; Kulovaara and Backlund 1993; Lindell et al. 1995), resulting in the accumulation of photorecalcitrant DOC (Thomas and Lara 1995; Naganuma et al. 1996). Geller (1986) observed a photochemical stimulation of bacterial growth potential on dissolved organic matter (DOM) from lake water sampled during winter but not for samples from the summer period. The decreased photoreactivity potential during summer noted by Geller (1986), as well as by other authors (Kulovaara and Backlund 1993; Lindell et al. 1995), may be explained by a limited capacity for photochemical production of biologically labile DOC from HMW organic matter. Still, DOC may continue to degrade upon further light exposure, forming less bioavailable end products and potentially causing an accumulation of nonlabile DOC (Keil and Kirchman 1994). Alternatively, there could be a complete photooxidation of DOC into inorganic forms (Granéli et al. 1996). In this case, depth and hydraulic residence time of the lake, as well as the input of DOC to the system, could be key factors regulating the DOC photosensitivity by affecting the mean exposure time of the DOC to solar radiation (Schindler et al. 1997).

We hypothesized that the potential for epilimnetic lake DOC to undergo photochemical reactions changes seasonally and depends on the previous exposure of the organic material to solar radiation. Two oligotrophic lakes of contrasting humic content were sampled monthly and the ability of artificial UV radiation to produce DIC and some LMW carboxylic acids was assessed. Two different irradiation treatments were used in order to evaluate the relative importance of short-wavelength UV radiation (UV-B, 280$320 \mathrm{~nm}$ ) relative to long-wavelength UV radiation (UV-A, $320-400 \mathrm{~nm}$ ) in this aspect. We hypothesized that the photooxidation potential would be high in winter and early spring, since DOC present in the lake at that time would have been largely protected from solar radiation during winter. In addition, photolabile DOC could have entered the lake from the drainage area and from the hypolimnion during lake turnover (Salonen and Vähätalo 1994). Consequently, potential photooxidation would be low in late summer and fall when the epilimnetic water has been extensively exposed to solar radiation during summer, while input of hypolimnetic water and water from the drainage area would have been prevented due to the stratification.

\section{Methods}

Photochemical reactivity of lake water DOC was studied in filtersterilized samples incubated in UV-transparent quartz tubes under an artificial radiation source. These lamps emitted UV radiation with intensities close to that observed at noon on a clear summer day in southern Sweden (Fig. 1). To evaluate the relative impor- tance of UV-B and UV-A radiation, respectively, we used a Mylar film to exclude wavelengths below $318 \mathrm{~nm}$ (Fig. 1). Two experiments were performed. In the first experiment, two lakes were sampled monthly. Changes in the production of DIC and four LMW carboxylic acids, as well as the decrease in fluorescence, absorbance, and DOC upon exposure to UV radiation, were followed in order to describe seasonal trends in potential DOC photoreactivity. The second experiment was a test of the methodology used in the first experiment, as well as being a detailed study of DIC production and $\mathrm{O}_{2}$ consumption during prolonged exposure of water samples to UV radiation. DIC is here defined as the sum of dissolved $\mathrm{CO}_{2}, \mathrm{H}_{2} \mathrm{CO}_{3}, \mathrm{HCO}_{3}{ }^{-}$, and $\mathrm{CO}_{3}{ }^{2-}$ and does not include $\mathrm{CO}$.

Two lakes of contrasting humic content were sampled in the seasonal study, Lake Fiolen (clear water) and Lake Skärshultsjön (humic) (Table 1). The lakes are situated in the region of the South Swedish highlands, close to the limnological field station at Aneboda (the Einar Naumann Laboratory, $57^{\circ} 07^{\prime} \mathrm{N}, 14^{\circ} 34^{\prime} \mathrm{E}$ ), about $30 \mathrm{~km}$ north of the city of Växjö. Both lakes are oligotrophic and have a low acid-buffering capacity with a few minor creeks entering the lakes. Lake Fiolen has a comparatively long hydraulic recidence time (4 years), a high transparency (Secchi depth 5$6 \mathrm{~m})$, clear water $\left(10 \mathrm{mg} \mathrm{Pt} \cdot \mathrm{L}^{-1}\right)$, and a median DOC content of $5.5 \mathrm{mg} \cdot \mathrm{L}^{-1}$. In contrast with Lake Fiolen, Lake Skärshultsjön may be characterized as a humic lake with a short retention time (7 months), a Secchi depth of less than $2 \mathrm{~m}$, brown water (80 mg Pt. $\mathrm{L}^{-1}$ ), and a DOC content of approximately $12 \mathrm{mg} \cdot \mathrm{L}^{-1}$ (Meili 1992). The lakes have previously been used in other studies of DOC photodegradation (cf. Lindell et al. 1995; Bertilsson and Tranvik 1998; Granéli et al. 1998). Sampling was performed approximately monthly (every 3-5 weeks) during more than a year (May 1995 to September 1996).

Meteorological data (solar radiation per month, mean air temperature, and total precipitation per month) were obtained from the Swedish Meteorological and Hydrological Institute at the nearby Växjö airport, $30 \mathrm{~km}$ southeast from the lakes (SMHI 1995, 1996).

Lake water was taken from the epilimnion at the deepest part of each lake using a 2-m-long, 50-mm inside diameter Plexiglas ${ }^{\mathrm{TM}}$ tube, which was emptied into a $10-\mathrm{L}$ polyethylene container. The water was stored cold $\left(+4^{\circ} \mathrm{C}\right)$ in the dark until measurements of photooxidation were performed (within 1-7 days). Water was pressure filtered stepwise through 142-mm Gelman A/E and $0.2-\mu \mathrm{m}$ membrane filters (Supor-200 ${ }^{\mathrm{TM}}$, Gelman Sci.) into 10-L Pyrex bottles. Finally, the water was filter-sterilized under low vacuum $(<300$ mbar $(30 \mathrm{kPa}))$ directly into quartz or borosilicate tubes (inside diameter $=40 \mathrm{~mm}$, length $=200 \mathrm{~mm}$, volume $=190 \mathrm{~mL}$ ) using $0.2-\mu \mathrm{m}$ VacuCap $^{\mathrm{TM}}$ filters (Gelman Sci.). Before use, tubes were first washed in dilute hydrochloric acid (1:10) and then thoroughly rinsed in deionized water and either autoclaved or heatsterilized overnight at $140^{\circ} \mathrm{C}$. Borosilicate tubes were wrapped in aluminium foil and were used as dark controls.

We discovered that the silicone stoppers used for sealing the tubes on the seven first sampling occasions (April-October 1995) released LMW carboxylic acids (acetic and formic acids) and also caused a production of DIC upon exposure to UV radiation. We made several tests to evaluate the degree of contamination. We incubated sterile filtered water from both lakes in quartz glass test tubes with stoppers made of both silicone and glass under the same intensity of UV-B and UV-A radiation as was used in the experiments, both in short- (1 day) and long-term (up to 5 days) exposures. Based on these tests, the results of the seven first sampling occasions for DIC and LMW carboxylic acids have been corrected for a silicone contamination approximately corresponding to $3 \mu \mathrm{g}$ $\mathrm{C} \cdot \mathrm{L}^{-1} \cdot \mathrm{h}^{-1}$ as DIC and $2 \mu \mathrm{g} \mathrm{C} \cdot \mathrm{L}^{-1} \cdot \mathrm{h}^{-1}$ as LMW carboxylic acids in Lake Fiolen (constituting 30 and 50\%, respectively, of photooxidation of DOC into DIC and LMW carboxylic acids in Lake Fiolen). We could not detect any release of organic molecules or DIC production from silicone stoppers in dark controls. For Lake 
Fig. 1. Spectral characteristics of the artificial light source used (dashed line) in comparison with natural solar radiation (solid line) in Lund (southern Sweden) at noon close to summer solstice. The transmission spectrum of the Mylar foil used to screen out UV-B radiation is also shown (dashed-dotted line).

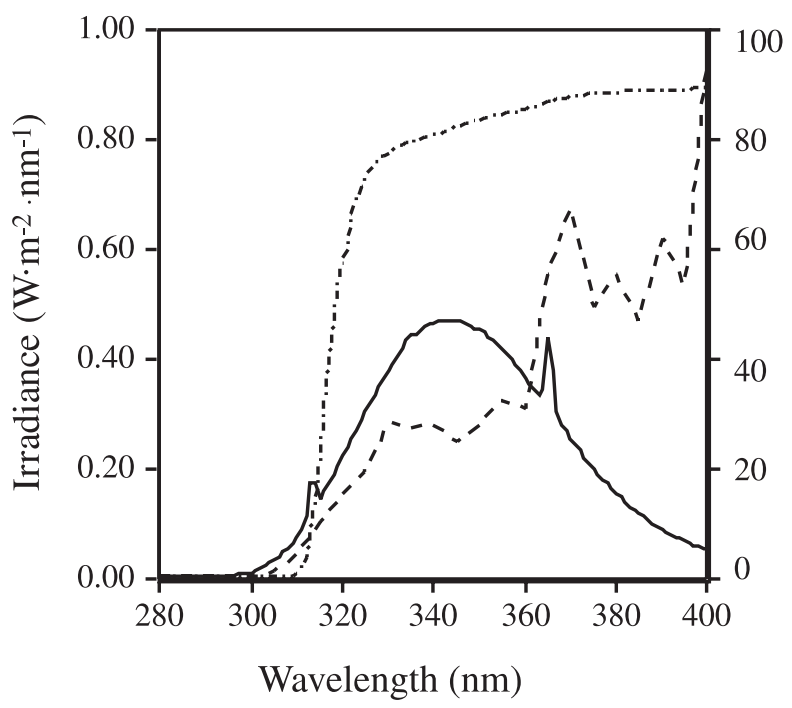

Skärshultsjön water, no significant photorelease from silicone stoppers to the water phase could be verified (probably due to the high photodegradation rates of DOC in water from Lake Skärshultsjön). Still, LMW carboxylic acids and DIC have been corrected as above. We changed to glass stoppers on the eighth sampling occasion (November 1995) and onward, and we strongly recommend that silicone not be used in any experimental setup exposed to light if, for example, organic molecules, DIC, or bacteria are to be studied.

The tubes with lake water were exposed horizontally at $19 \pm$ $1{ }^{\circ} \mathrm{C}, 30 \mathrm{~cm}$ beneath eight lamps (UV-A-340, Q-Panel Co.) emitting both UV-B and UV-A radiation. The UV-B radiation $\left(1.91 \mathrm{~W} \cdot \mathrm{m}^{-2}\right)$ was similar to the natural solar radiation at noon during clear summer conditions in southern Sweden $\left(1.5-2.0 \mathrm{~W} \cdot \mathrm{m}^{-2}\right)$, but the UV-A radiation $\left(23 \mathrm{~W} \cdot \mathrm{m}^{-2}\right)$ was slightly lower than natural solar radiation $\left(35 \mathrm{~W} \cdot \mathrm{m}^{-2}\right)$ due to low emission in the longer UV-A wavelength bands (Fig. 1). The tubes also emit radiation in the photosynthetically active radiation (PAR) wavelength band but at low intensities $\left(<5 \mathrm{~W} \cdot \mathrm{m}^{-2}\right)$. Incubations lasted for $22 \pm 2 \mathrm{~h}$. An exposure of $24 \mathrm{~h}$ is equal to UV-B radiation of $170 \mathrm{~kJ} \cdot \mathrm{m}^{-2}$ and UV-A radiation of $2000 \mathrm{~kJ} \cdot \mathrm{m}^{-2}$ (total UV radiation of $2170 \mathrm{~kJ} \cdot \mathrm{m}^{-2}$ ), approximately corresponding to 7 days of UV-B radiation and 4 days of UV-A radiation during summer in southern Sweden. It should also be noted that the PAR component of solar radiation is active in the photodegradation of DOC (Granéli et al. 1998). Spectral irradiance of the radiation source was measured with a spectroradiometer (model 752, Optronics Lab.) at the beginning of the study (Fig. 1). Any changes in radiation intensities due to ageing of light tubes were followed throughout the study by using a radiometer (IL1400A, International Light Inc.) connected to broad-band UV-A and a UV-B sensors. Four light tubes were replaced during the period to maintain constant radiation emission from the lamps. One set of samples $(n=5)$ from each lake was exposed to full radiation, a second set was covered with Mylar foil (Du Pont de Nemours ${ }^{\circledR}$; quality Mylar $\mathrm{D}^{\mathrm{TM}}$, cutoff at $318 \mathrm{~nm}$ ) excluding UV-B radiation (Fig. 1), and a third set of tubes was covered with aluminium foil for use as dark controls.

After incubation, the tubes were first used for DIC analysis. At least three DIC measurements were made for each tube, resulting in a coefficient of variation of less than $2 \%$ (see Granéli et al. 1996). DIC was calibrated using standard solutions of carbonate in serum bottles.
Sterile filtered water $(0.2 \mu \mathrm{m})$ for analysis of DOC was transferred into acid-rinsed, precombusted $\left(+500^{\circ} \mathrm{C}\right.$ overnight $)$ glass vials with Teflon-lined screw caps, stored at $4^{\circ} \mathrm{C}$, and analysed no more than 3 days after the irradiation. DOC was analysed by the Ptcatalysed high-temperature combustion method using a Shimadzu TOC-5000 total carbon analyser (Granéli et al. 1996).

The concentrations of some LMW carboxylic acids (acetic, formic, malonic, and oxalic acids) were measured in frozen subsamples using a previously described capillary ion electrophoresis based method (Bertilsson and Tranvik 1998). Duplicate subsamples were analysed on a Quanta 4000 capillary electrophoresis system (Millipore) equipped with a fused silica capillary (75 $\mu \mathrm{m}$ inner diameter). The mobile phase was a 1,2,4,-benzene tricarboxylic acid buffer ( $\mathrm{pH} 7.9)$ with an electroosmotic flow modifier (0.5 mM). An electrokinetic preconcentration at $5 \mathrm{kV}$ was used to inject samples, and a separation voltage of $15 \mathrm{kV}$ was applied. These settings directed both the electroosmotic flow of the buffer and the flow of analytes towards the capillary outlet, where analytes were detected by universal indirect UV detection at $254 \mathrm{~nm}$. Molybdate was added to all samples as an internal standard, and standard curves (linear regression, $r^{2}>0.99, n>4$ ) were obtained by spiking selected samples with a concentrated mixed standard solution to obtain final concentrations exceeding maximum concentrations in experimental incubations.

Aliquots of water from the irradiated water and dark controls were used for measurements of absorbance at $250 \mathrm{~nm}$ using a Beckman $\mathrm{DU}^{\circledR} 650$ spectrophotometer equipped with a $1-\mathrm{cm}$ quartz cuvette.

Humic substance fluorescence was measured using a Shimadzu RF-1501 spectrofluorometer equipped with a $10 \times 10 \mathrm{~mm}$ quartz cuvette, with excitation at $355 \mathrm{~nm}$ and emission at $455 \mathrm{~nm}$ (bandwidths $=10 \mathrm{~nm}$ ). For each series of measurements, fluorescence was calibrated against a $0.01 \mathrm{M}$ quinine sulphate solution in sulphuric acid.

Mean production rates of DIC and the measured LMW carboxylic acids for each treatment were calculated. Observed differences between light and dark treatments were interpreted as photochemical DIC or LMW carboxylic acid production from DOC. The difference between full radiation and Mylar-covered treatments was considered to reflect the effect from UV-B radiation.

The second experiment was performed on sterile filtered water from the two lakes sampled in August 1996. The water was continuously exposed to the same UV radiation source as above (Fig. 1) for up to 11 days $(261 \mathrm{~h})$ in order to follow an extended photodegradation of DOC. The radiation dose for this period was UV-B at $1800 \mathrm{~kJ} \cdot \mathrm{m}^{-2}$ and UV-A at $18900 \mathrm{~kJ} \cdot \mathrm{m}^{-2}$. The total exposure period corresponded to approximately 30 days of summertime UV-B and 40 days of corresponding UV-A irradiation under natural sunlight in southern Sweden. Duplicate samples from each lake and treatment were analysed every second day for DIC, DOC, dissolved $\mathrm{O}_{2}$, fluorescence, and absorbance at $250 \mathrm{~nm}$.

DIC analyses were performed as described above, and tubes were then immediately sampled for dissolved $\mathrm{O}_{2}$ (Winkler titration). Water was aspirated with a $50-\mathrm{mL}$ syringe connected to a silicone tubing that reached almost to the bottom of the quartz tube. Oxygen reagents were added into the filled syringe with cannulae attached to automatic micropipettes. Dissolved $\mathrm{O}_{2}$ was analysed after dissolution of the precipitate using automatic potentiometric titration (Granéli and Granéli 1991).

Potential growth of microbes in the tubes during the experiments was monitored by flow cytometric analyses (Becton Dickinson FACSort) of samples preserved in $2 \%$ formaldehyde. Cells were stained with the nucleic acid stain SYTO ${ }^{\circledR} 13$ (Molecular Probes, Eugene, Oreg.), and a standard solution containing fluorescent beads was used as reference (del Giorgio et al. 1996).

Statistical analyses were performed on log-transformed data. We applied ANOVA with Fisher's PLSD post hoc test and linear re- 
Table 1. Characteristics of the two studied lakes during May 1995 to August 1996.

\begin{tabular}{|c|c|c|}
\hline & Fiolen & Skärshultsjön \\
\hline Lake area $\left(\mathrm{km}^{2}\right)^{a}$ (\% of catchment) & $1.58(31 \%)$ & $0.36(5 \%)$ \\
\hline Catchment area $\left(\mathrm{km}^{2}\right)^{a}$ & 5.05 & 8 \\
\hline Forest $(\%)$ & 50 & 90 \\
\hline Agriculture (\%) & 13 & 5 \\
\hline Pastures $(\%)$ & 6 & 1 \\
\hline Bogs $(\%)$ & 0 & 4 \\
\hline Retention time (theoretical) ${ }^{a}$ & 4 years & 7 months \\
\hline $\mathrm{DIC}\left(\mathrm{mg} \cdot \mathrm{L}^{-1}\right)$ & $0.7(0.5-1.6)$ & $0.4(0.2-1.9)$ \\
\hline $\mathrm{DOC}\left(\mathrm{mg} \cdot \mathrm{L}^{-1}\right)$ & $5.5(4.1-6.5)$ & $11.9(8.2-13.6)$ \\
\hline Absorbance at $430 \mathrm{~nm}\left(\mathrm{~cm}^{-1}\right)$ & $0.005(0.003-0.008)$ & $0.031(0.024-0.042)$ \\
\hline $\mathrm{pH}^{b}$ & 6.5 & 5.5 \\
\hline Fluorescence (QSU) & $3.4(1.2-5.5)$ & $18.8(5.7-29.2)$ \\
\hline Secchi depth $(\mathrm{m})^{b}$ & 5.5 & 1.8 \\
\hline Water color $\left(\mathrm{mg} \mathrm{Pt} \cdot \mathrm{L}^{-1}\right)^{b}$ & 5 & 90 \\
\hline
\end{tabular}

Note: Values are medians (maximum and minimum values for the sampling period given in parentheses).

${ }^{a}$ From Bengtsson et al. (1965) and Meili (1992).

${ }^{b}$ From Granéli et al. (1996).

gression, unless otherwise stated. Each tube was considered to constitute one independent sample.

\section{Results}

\section{Meteorological conditions and DOM in situ}

Spring in 1995 was rainy, with a following summer (July and August) characterized by hot, sunny weather with little precipitation (Fig. 2). At the end of August, solar radiation decreased and remained low (about 20\% of summer values) from the end of October 1995 until February 1996. The solar radiation from April through August (spring and summer) constituted approximately $75 \%$ of the total radiation per calendar year. The ice cover lasted for 5 months (November 1995 until April 1996) due to an unusually cold, dry, and long winter. The solar radiation increased in spring, with a sunny April, but May 1996 was cloudy with little radiation and high precipitation. The radiation reached normal values at the end of July and remained so through August, but generally, the summer of 1996 was relatively rainy and cold with low sunlight intensities compared with the previous summer (Fig. 2).

DOC in Lake Fiolen varied from 4.1 to $6.5 \mathrm{mg} \cdot \mathrm{L}^{-1}$ (median $5.5 \mathrm{mg} \cdot \mathrm{L}^{-1}$ ) and in Lake Skärshultsjön from 8.2 to $13.6 \mathrm{mg} \cdot \mathrm{L}^{-1}$ (median $11.9 \mathrm{mg} \cdot \mathrm{L}^{-1}$ ) (Table 1 ). DOC-specific absorbance (at $250 \mathrm{~nm}$ ) was rather constant for each individual lake during the complete sampling period but was approximately twice as high in the humic lake compared with the clearwater lake (Fig. 3).

\section{Treatment effects}

Generally, samples from the three different treatments (UV-A+B, UV-A, and dark) differed significantly in DIC concentration, fluorescence, and absorbance ( $p<0.0001)$. These differences were observed for both lakes and for each individual sampling occasion, with the exception of some sampling occasions in Lake Fiolen, where no significant differences in DIC concentration could be found between UVA+B-exposed and UV-A-exposed samples (see Fig. 4). Photooxidative DIC production in water from Lake Fiolen (samples exposed to full radiation) varied between 3.5 and $8.9 \mu \mathrm{g} \cdot \mathrm{L}^{-1} \cdot \mathrm{h}^{-1}$ (median $6.5 \mu \mathrm{g} \cdot \mathrm{L}^{-1} \cdot \mathrm{h}^{-1}$ ), and the corresponding rates for Lake Skärshultsjön were between 28.5 and $56.7 \mu \mathrm{g} \cdot \mathrm{L}^{-1} \cdot \mathrm{h}^{-1}$ (median $47.2 \mu \mathrm{g} \cdot \mathrm{L}^{-1} \cdot \mathrm{h}^{-1}$ ) (Table 2; Fig. 4). The production in UV-A-irradiated water from Lake Fiolen corresponded to $57 \%$ (median) of DIC production in samples exposed to the total radiation (range 41-73\%), while for Lake Skärshultsjön water, the median was $74 \%$ (range 62$83 \%$ ). Thus, for the radiation source used, UV-B radiation was responsible for 43 and $26 \%$ of total DIC production in water from Lakes Fiolen and Skärshultsjön, respectively. DIC production was positively related to initial DOC content, fluorescence, and absorbance at $250 \mathrm{~nm}(p<0.005)$ in both lakes and for both irradiation treatments $(\mathrm{UV}-\mathrm{A}+\mathrm{B}$ and UV-A alone).

The decrease in DOC could not be measured with the same precision as the increase in DIC (cf. Granéli et al. 1996). In water from Lake Fiolen, we rarely found any significant decrease in DOC after light exposure, and there was no significant correlation between irradiation-induced DIC production and changes in DOC $(p>0.05)$. We did not observe any correlation between DIC production and decreased fluorescence or absorbance at any of the measured wavelengths $(p>0.05)$. On the other hand, the DOC concentrations differed significantly between the UV-irradiated samples and the dark controls in water from Lake Skärshultsjön $(p<0.001)$. There were rarely any significant differences between the two types of irradiation (UV-A+B and UV-A alone). DIC production was positively related to the decrease in DOC in water from Lake Skärshultsjön $(p<$ $0.0001)$ as well as to loss of fluorescence $(p<0.005)$ and loss of absorbance at $250 \mathrm{~nm}(p<0.005)$ for this lake.

The pooled concentrations of the four analysed carboxylic acids (oxalic, malonic, formic, and acetic acids) differed significantly between dark controls and the two irradiation treatments for water from both Lakes Fiolen and Skärshultsjön $(p<0.0001)$. Generally, the pooled concentration of these acids in dark controls was less than $10 \%$ of the concentration observed in water exposed to full radiation. Among the four analysed carboxylic acids, formic and acetic 
Fig. 2. Solar radiation measurements at Växjö airport, situated $30 \mathrm{~km}$ southeast from the two sampled lakes, lakes Fiolen and Skärshultsjön. Global radiation represents energy from the complete solar spectrum (300-3000 nm), while sun hours represent the number of hours per month with total solar radiation of more than $120 \mathrm{~W} \cdot \mathrm{m}^{-2}$ (summertime, normally between 09:00 and 17:00). Arrows indicate approximate date of sampling. Solid lines, 1995-1996; broken lines, average for 1983-1994. (Data from SMHI 1995, 1996.)

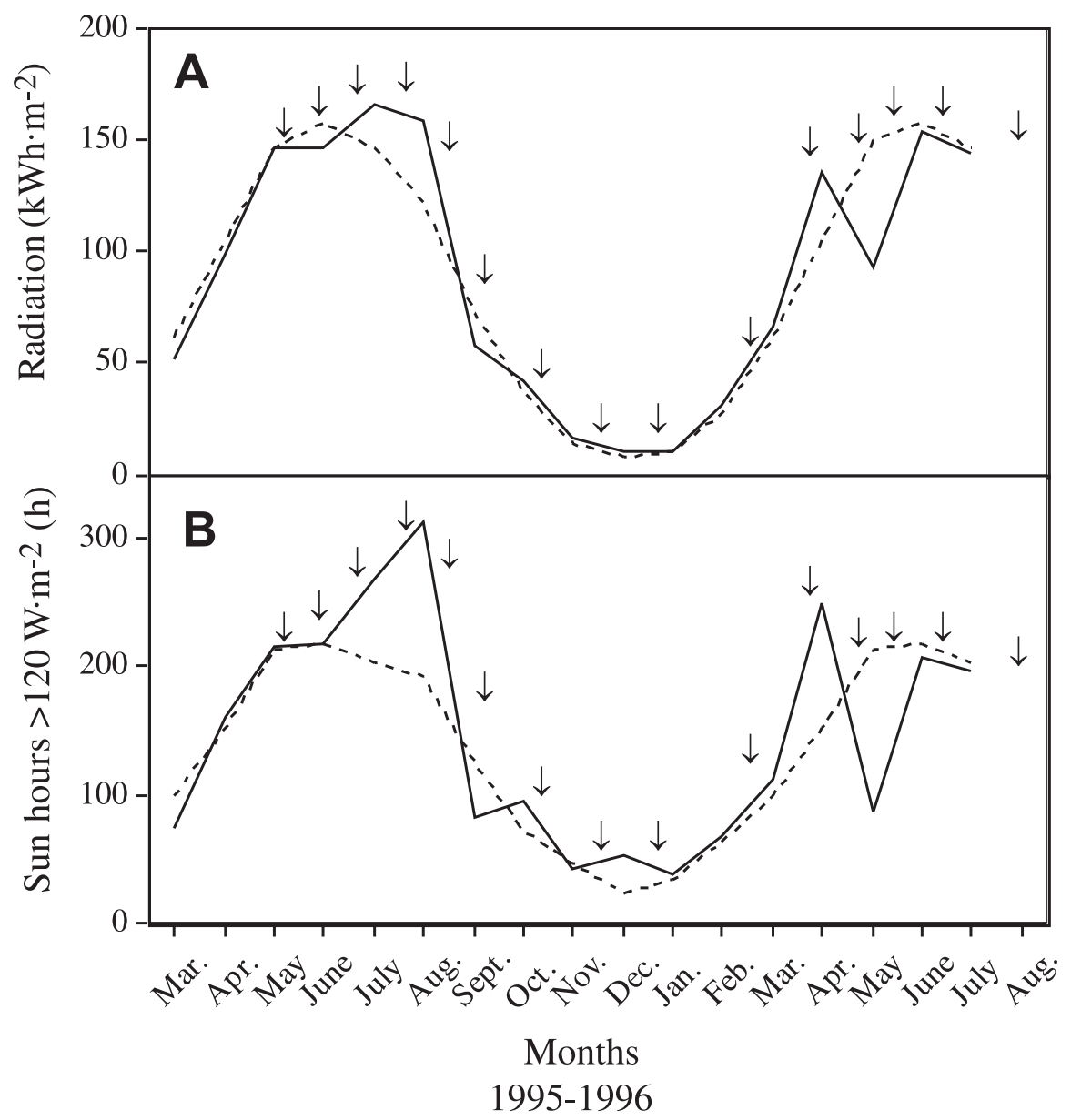

Fig. 3. DOC-specific absorbance of surface water during the sampling period in Lakes Skärshultsjön (squares) and Fiolen (diamonds).

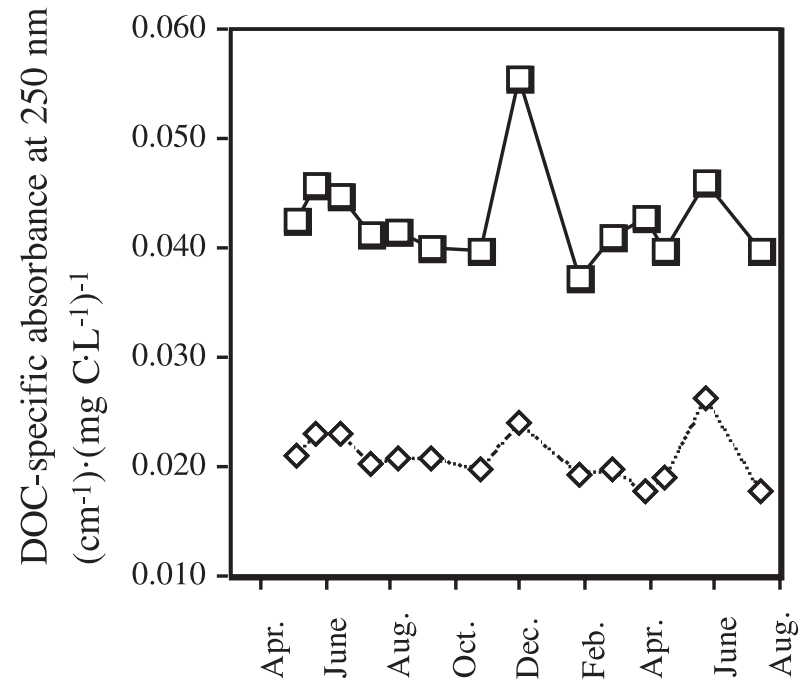

Months 1995-1996 acids were the major intermediates produced (Table 3 ). Combined, they accounted for approximately $80 \%$ of the total carbon retrieved in the four analysed compounds for both Lakes Fiolen and Skärshultsjön (median throughout the sampling period). The pooled production of the four carboxylic acids in water from Lake Fiolen ranged between 1.7 and $3.7 \mu \mathrm{g}$ $\mathrm{C} \cdot \mathrm{L}^{-1} \cdot \mathrm{h}^{-1}$ (UV-A+B-exposed samples), while for Lake Skärshultsjön, corresponding production rates were between 6.2 and $21.4 \mu \mathrm{g} \mathrm{C} \cdot \mathrm{L}^{-1} \cdot \mathrm{h}^{-1}$ (Table 2). UV-A radiation alone explained 49\% (median) (range 19-83\%) of the production in Lake Fiolen water and 62\% (median) (range 48-79\%) in water from Lake Skärshultsjön.

\section{Seasonal variations in DOC photoreactivity}

Photooxidative DIC production and photoproduction of the four measured LMW carboxylic acids varied with sampling occasion for both Lakes Fiolen and Skärshultsjön ( $p<$ 0.0001 ). DIC production was lowest in late summer for both lakes, while this rate was higher in winter and early spring (Fig. 4A). This pattern was also observed for carboxylic acid production in Lake Skärshultsjön, while no such strong seasonal pattern was observed for Lake Fiolen (Fig. 5A). DOCnormalized DIC production was 3.2 times higher (median) in Lake Skärshultsjön water compared with water from Lake 
Fig. 4. (A) Potential DIC production rates in samples exposed to an artificial light source during May 1995 to August 1996, (B) DOCnormalized rates, and (C) absorbance-normalized $(250 \mathrm{~nm})$ rates. Open symbols indicate samples exposed to both UV-A and UV-B radiation, and half-solid symbols indicate Mylar-covered samples (i.e., exposed only to UV-A). The interval for silicone stoppers has been corrected for silicone contamination (see text). Error bars indicate 95\% confidence intervals (fell within symbols) of arithmetric means $(n=5)$.

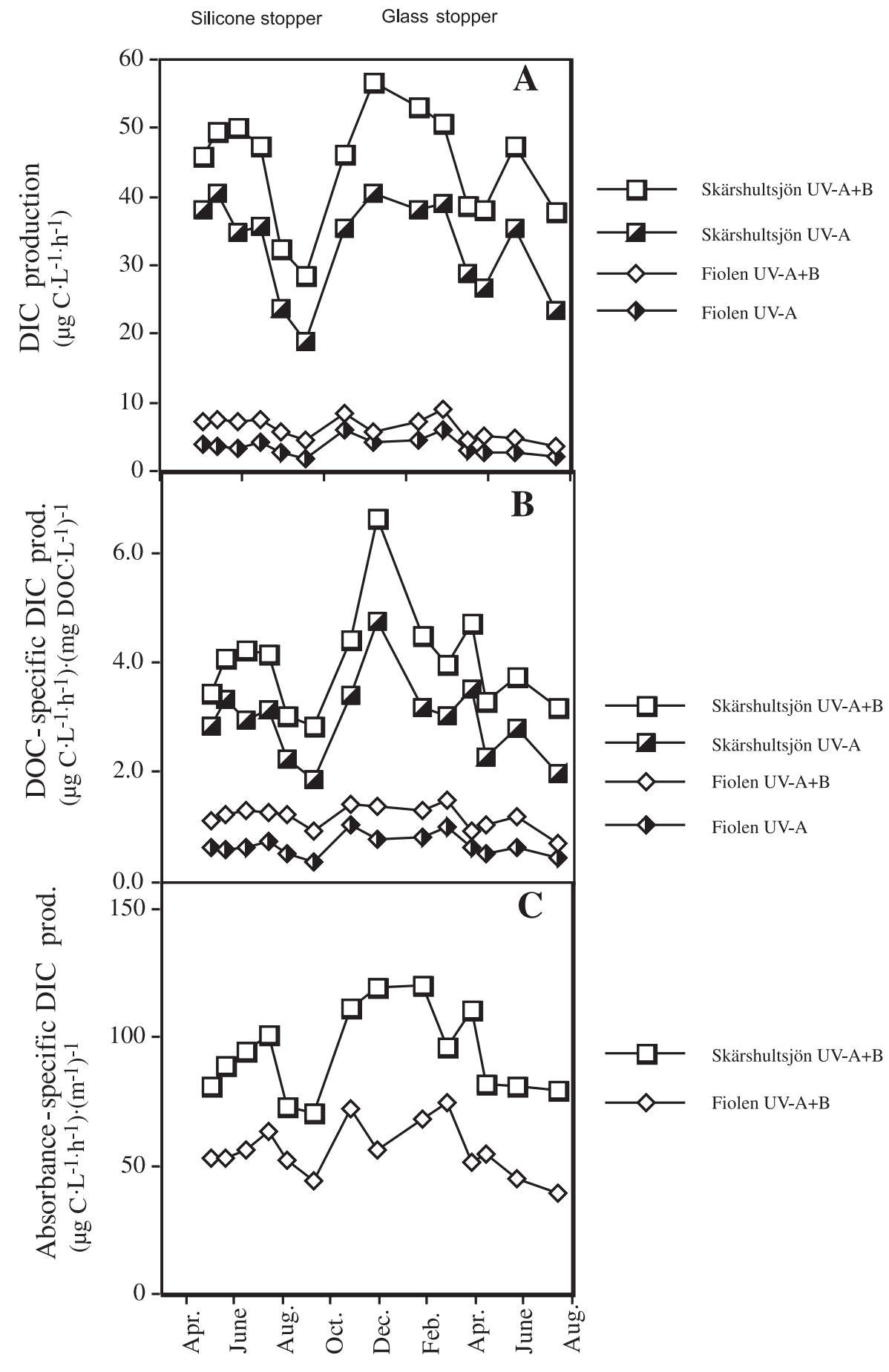

Months 1995-1996

Fiolen (Fig. 4B). The DOC-normalized, pooled production of oxalic, formic, malonic, and acetic acids was approximately 2.7 times higher in water from the humic Lake Skärshultsjön compared with water from the clearwater Lake Fiolen (median through the period) (Fig. 5B). Since the
DOC-specific absorbance did not change markedly in any of the lakes during the experimental period (Fig. 3), seasonal trends in DOC- and absorbance-normalized photoproduction of DIC and pooled carboxylic acids were rather similar (cf. Figs. 4 and 5). The normalization for absorbance did, how- 
Table 2. Rates of photochemical DIC production, LMW carboxylic acid release, and DOC consumption in UV-A+B-exposed samples of the two investigated lakes during May 1995 to August 1996.

\begin{tabular}{lll}
\hline & Fiolen & Skärshultsjön \\
\hline DIC production $\left(\mu \mathrm{g} \mathrm{C} \cdot \mathrm{L}^{-1} \cdot \mathrm{h}^{-1}\right)(n=15)$ & $6.5(3.5-8.9)$ & $47.2(28.5-56.7)$ \\
LMW carboxylic acid production $\left(\mu \mathrm{g} \mathrm{C} \cdot \mathrm{L}^{-1} \cdot \mathrm{h}^{-1}\right)(n=8)$ & $2.1(1.7-3.7)$ & $12.9(6.2-21.4)$ \\
DOC consumption $\left(\mu \mathrm{g} \mathrm{C} \cdot \mathrm{L}^{-1} \cdot \mathrm{h}^{-1}\right)(n=15)$ & $5(-25-18)$ & $50(9.5-93)$ \\
\hline
\end{tabular}

Note: Values are medians (ranges for the sampling period are given in parentheses).

Table 3. Photoproduction of some LMW carboxylic acids in UV-A+B-exposed samples of the two investigated lakes during May 1995 to August 1996.

\begin{tabular}{lll}
\hline & Fiolen & Skärshultsjön \\
\hline Formic acid $\left(\mu \mathrm{g} \mathrm{C} \cdot \mathrm{L}^{-1} \cdot \mathrm{h}^{-1}\right)$ & $0.97(0.56-1.86,41 \%)$ & $5.86(2.50-9.98,46 \%)$ \\
Acetic acid $\left(\mu \mathrm{g} \mathrm{C} \cdot \mathrm{L}^{-1} \cdot \mathrm{h}^{-1}\right)$ & $0.92(0.54-1.86,39 \%)$ & $3.72(1.68-7.97,29 \%)$ \\
Malonic acid $\left(\mu \mathrm{g} \mathrm{C} \cdot \mathrm{L}^{-1} \cdot \mathrm{h}^{-1}\right)$ & $0.35(0.14-0.48,15 \%)$ & $2.69(1.66-3.73,21 \%)$ \\
Oxalic acid $\left(\mu \mathrm{g} \mathrm{C} \cdot \mathrm{L}^{-1} \cdot \mathrm{h}^{-1}\right)$ & $0.11(0.00-0.34,5 \%)$ & $0.51(0.28-0.79,4 \%)$ \\
\hline
\end{tabular}

Note: Values are medians (minimum-maximum range and percentage of total carboxylic acid production for the sampling period are given in parentheses).

ever, even out the differences in photoreactivity between the two lakes.

\section{Long time exposure}

In the long time exposure, DIC increased, while dissolved $\mathrm{O}_{2}$ decreased with increasing light exposure (Fig. 6). For water from Lake Fiolen, DIC had increased by $0.58 \mathrm{mg} \cdot \mathrm{L}^{-1}$ at the end of the 11-day incubation, while DOC had decreased by $0.71 \mathrm{mg} \cdot \mathrm{L}^{-1}$. Corresponding figures for irradiated water from Lake Skärshultsjön were 3.2 and $3.4 \mathrm{mg} \mathrm{C} \cdot \mathrm{L}^{-1}$. Approximately 13 and $25 \%$, respectively, of the initial DOC content in the samples from Lakes Fiolen and Skärshultsjön had been photooxidized to DIC after 11 days. These are probably not maximal values for DOC photooxidation to DIC, since DIC increased continously for the Lake Fiolen samples during the course of the incubation, albeit with a decreasing rate (Fig. 6). On the other hand, DIC accumulation ceased abruptly for water from Lake Skärshultsjön after some $100 \mathrm{~h}$ of UV exposure, which was likely due to $\mathrm{O}_{2}$ limitation (Fig. 6). Dissolved $\mathrm{O}_{2}$ never decreased below $80 \%$ saturation in Lake Fiolen, while a $25 \% \mathrm{O}_{2}$ saturation was reached after $100 \mathrm{~h}$ of exposure in Lake Skärshultsjön (equal to $8700 \mathrm{~kJ} \cdot \mathrm{m}^{-2}$ ). No additional photooxidation was observed after reaching this low $\mathrm{O}_{2}$ concentration. The pooled data sets from the two lakes were used for comparison between DIC production and $\mathrm{O}_{2}$ consumption, since the linear relationship between these parameters did not differ between the systems ( $t$ test of slopes, $p>0.05$ ). The loss of dissolved $\mathrm{O}_{2}$ after irradiation was linearly correlated with DIC production for the pooled data set $(p<0.0001)$. The molar ratio of $\mathrm{O}_{2}$ consumption to $\mathrm{CO}_{2}$ evolution was close to 1 (slope $=0.86$, $\left.r^{2}=0.974\right)$. Changes in DIC and $\mathrm{O}_{2}$ concentrations in the dark controls during the 261-h exposure were small compared with changes in irradiated tubes (Fig. 6).

For both lakes, fluorescence and absorbance at $250 \mathrm{~nm}$ decreased markedly with irradiation time, while changes were small in dark controls (Fig. 7). For the pooled data set, a significant correlation was observed between loss of absorbance at $250 \mathrm{~nm}$ and loss of fluorescence $(p<0.005$, $\left.r^{2}=0.92\right)$. Furthermore, both of these parameters were correlated with DIC production $\left(p<0.0001, r^{2}=0.99\right.$ and 0.94 for fluorescence and absorbance, respectively). No further bleaching of optical properties occurred at the low $\mathrm{O}_{2}$ concentrations obtained after some $100 \mathrm{~h}$ of irradiation of Lake Skärshultsjön water (Fig. 7). For dark controls, changes in absorbance and fluorescence were small compared with irradiated samples.

At the end of the 11-day incubation, we observed small numbers of bacteria in the dark controls. No such growth of bacteria could be observed in irradiated treatments. The numbers of bacteria were always less than 100000 cells $\cdot \mathrm{mL}^{-1}$, and the counted cells were also very small and had a signal close to the detection limit of the flow cytometer. Final cell numbers in the seasonal 24-h incubations were always lower compared with the 11-day experiment. Both DIC and $\mathrm{O}_{2}$ increased somewhat in dark controls in the long time exposure, contrary to what would have been expected if bacterial respiration had been significant. The increase in DIC and $\mathrm{O}_{2}$ could be due to a small diffusion of gases into the tubes during the course of the long incubation.

\section{Discussion}

\section{Seasonal trends and differences between lakes}

Potential of lake water DOC to undergo photodegradation varied throughout the 16-month-long sampling period of the present study. Seasonal changes in potential photodegradation were more noticeable for the humic than for the clearwater lake. Furthermore, photochemical DIC and carboxylic acid formation rates were about eight and six times higher, respectively, in the humic lake. These differences can only partially be explained by the twofold higher DOC concentration in Lake Skärshultsjön. In addition, the quality of the organic matter and in particular the DOCspecific UV absorbance would be a plausible regulator of photochemical reaction rates, since the absorption of photons is a prerequisite for photochemical reactions to occur. Accordingly, a normalization for absorbance at $250 \mathrm{~nm}$ decreased the apparent differences in photochemical reactivity between Lakes Skärshultsjön and Fiolen markedly, even if seasonal variations were not affected to any major extent. In conclusion, neither DOC nor absorbance could satisfactorily 
Fig. 5. (A) Potential production rates of pooled oxalic, malonic, formic, and acetic acids in samples exposed to an artificial radiation source during May 1995 to August 1996, (B) DOC-normalized rates, and (C) absorbance-normalized (250 nm) rates. Open symbols indicate samples exposed to both UV-A and UV-B radiation, and half-solid symbols indicate Mylar-covered samples (i.e., exposed only to UV-A). Error bars (occassionally hidden in the symbols) are 95\% confidence intervals of aritmetric means $(n=3)$. Note that only every second sampling occassion has been analysed.

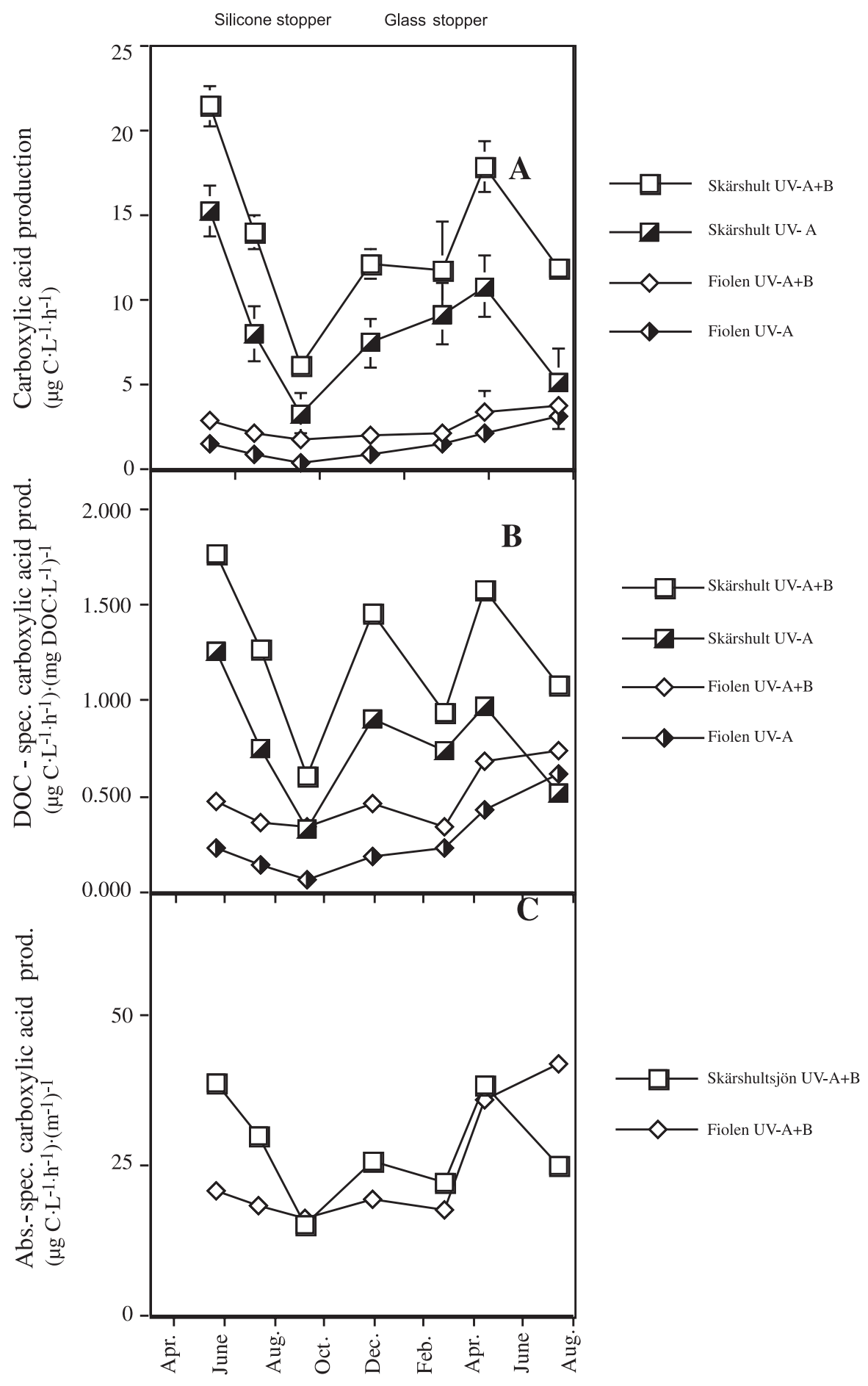

Months 1995-1996

explain within-lake changes in photochemical reactivity potential but could be useful for evaluation of cross-system differences.

The observation that DOC may have variable photo- sensitivity, not only between systems of different humic content but also during a season within a single lake, is in accordance with Clair and Sayer (1997), who observed similar seasonal trends in chromophoric groups in DOC from 
Fig. 6. DIC and dissolved $\mathrm{O}_{2}$ for samples from lakes Skärshultsjön and Fiolen in relation to duration of continuous long-term irradiation. Squares represent DIC concentrations and circles dissolved $\mathrm{O}_{2}$. Solid symbols represent dark-incubated samples and open symbols represent samples incubated in UV$\mathrm{A}+\mathrm{B}$ radiation. Dashed lines were drawn by eye, while continous lines were best fits (linear or second-order polynomial).

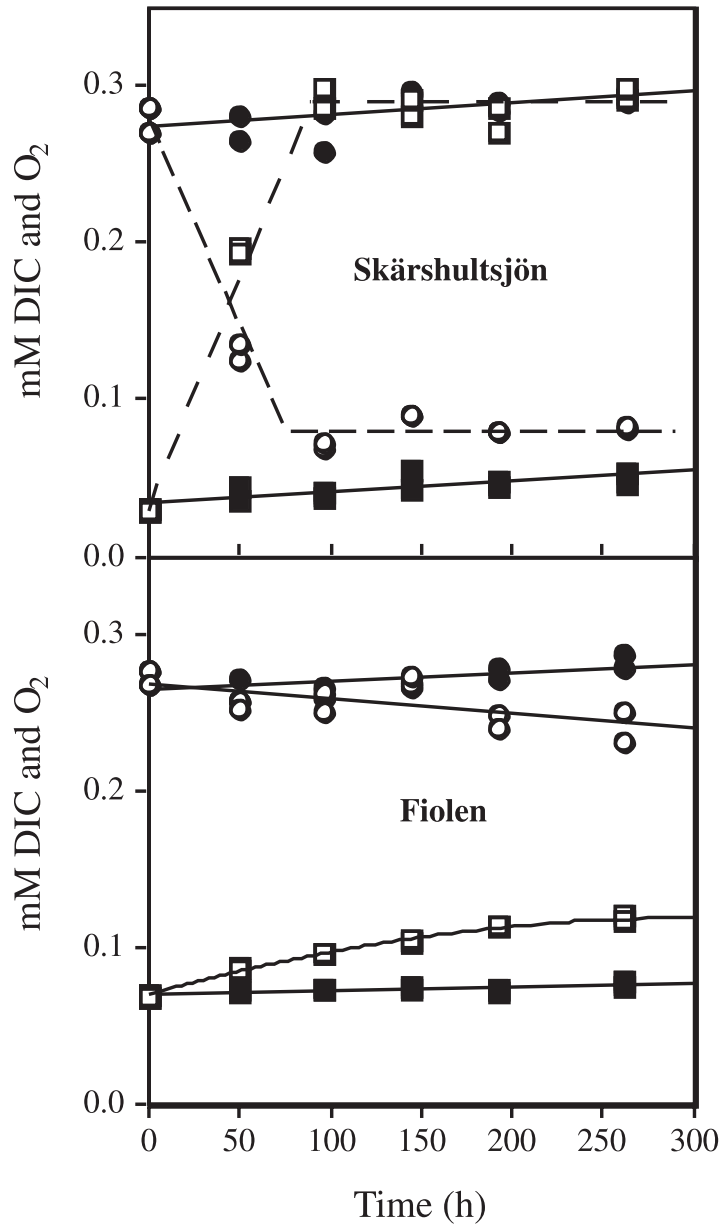

Canadian lakes. One possible reason for the observed variation in photoreactivity could be that a prolonged exposure to solar radiation might result in a gradual increase in the fraction of more photorecalcitrant DOC (Thomas and Lara 1995), presumably of low bacterial availability (Geller 1986; Lindell et al. 1995). Hence, the longer the hydraulic residence time, the longer the exposure of each individual organic molecule to solar radiation. The consequences for Lake Fiolen, which has a relatively long hydraulic recidence time (4 years), would be a low DOC-specific photoreactivity in the surface layer. This is in agreement with the results obtained in the present study. This is also in accordance with earlier studies in some Canadian lakes, where long residence times were correlated with a decrease in DOC-specific absorbance and fluorescence (Curtis and Schindler 1997). Still, the suggested importance of hydraulic residence time in the present study is based on results from no more than two lakes, and we do not highlight other potentially important variables, such as differences in DOC origin as well as the more detailed quality of the organic material.

Granéli et al. (1996) measured depth-integrated photo-
Fig. 7. Absorbance at $250 \mathrm{~nm}$ and fluorescence for long-termincubated samples under continous UV radiation. Squares represent data points for Lake Fiolen samples, and circles retresent data for Lake Skärshultsjön samples. Solid symbols represent dark-incubated controls and open symbols represent samples incubated in UV-A+B radiation. Dashed lines were drawn by eye, while continous lines were best fits (linear).

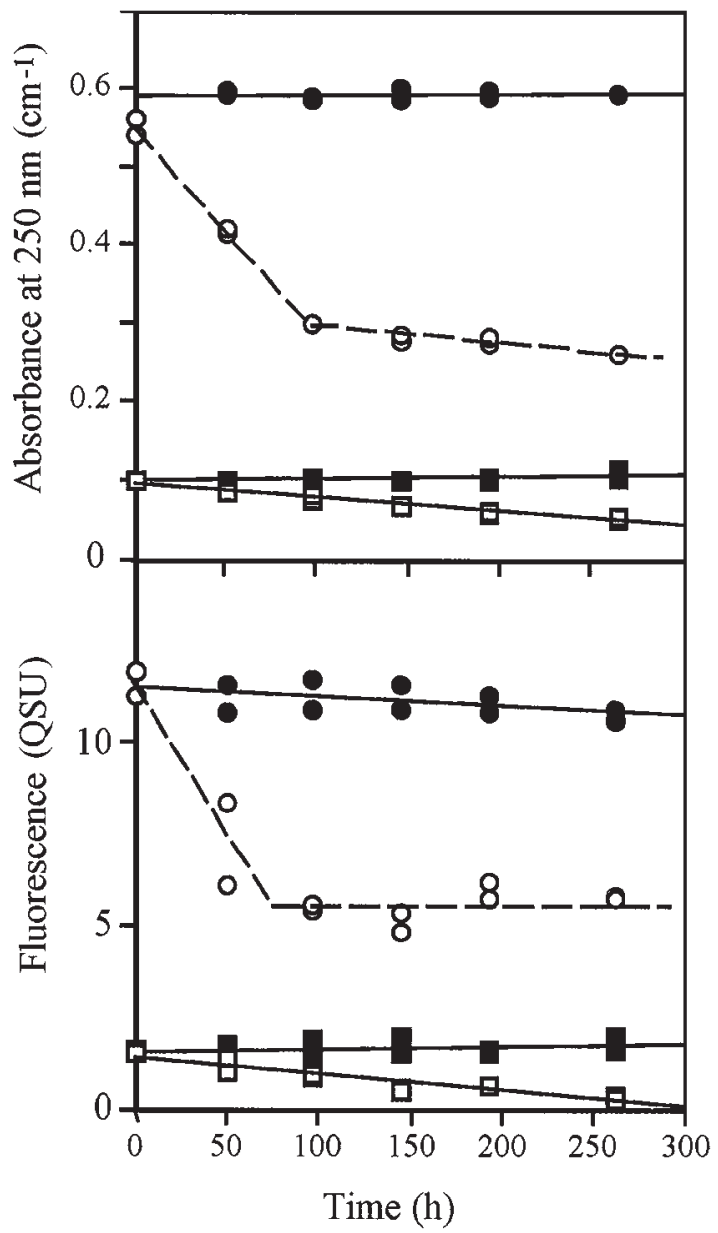

oxidation rates in Lake Fiolen, Lake Skärshultsjön, and some other lakes of varying humic content. They found that depth-integrated DIC production was similar among most studied lakes, irrespective of humic content. This may seem contradictory given the lower DOC-specific photoreactivity reported for the oligohumic lake in the present study. However, the results in the present study only consider surface processes, while the study of Granéli et al. (1996) involved in situ incubations at several depths during a whole summer day, thus taking into account the vertical attenuation of sunlight, which is not the focus of the present study. The lower rate of photooxidation at the surface of the clear lake is compensated for by a much deeper layer of photooxidation.

\section{DIC production and $\mathrm{O}_{2}$ consumption}

In the extended exposure experiment, photochemical $\mathrm{O}_{2}$ consumption was proportional to DOC content, and the molar $\mathrm{O}_{2}$ consumption to $\mathrm{CO}_{2}$ evolution ratio was close to 1 (0.84). This is in agreement with earlier studies (Miles and Brezonik 1981; Lindell and Rai 1994). In Lake Skärshultsjön, DIC production and $\mathrm{O}_{2}$ consumption continued 
until dissolved $\mathrm{O}_{2}$ concentration reached $25 \%$ of saturation. Below 25\% saturation, no photooxidation could be detected. Oxygen availability appears to be a limiting factor for photodegradation of DOC (Miles and Brezonik 1981; Lindell and Rai 1994). This could explain the observed decrease in photoproduction of DIC for Lake Skärshultsjön after the prolonged exposure in experimental enclosures. However, such an $\mathrm{O}_{2}$ depletion effect would not influence the photoreactivity rates obtained in the seasonal study to any larger extent, since employed incubation times in the seasonal study were significantly shorter $(22 \pm 2 \mathrm{~h})$.

\section{Photoproduction of LMW carboxylic acids}

The average pooled photoproduction of oxalic, malonic, formic, and acetic acids in water from Lakes Fiolen and Skärshultsjön was close to $30 \%$ of the DIC photoproduction (in carbon units). Thus, photooxidation of DOC to DIC (Salonen and Vähätalo 1994; Granéli et al. 1996) appears to be a quantitatively dominant process compared with photoproduction of biologically labile LMW substrates. Still, the amount of LMW substrates produced relative to DIC was probably an underestimate, since we only measured the photoproduction of four different LMW carboxylic acids (oxalic, malonic, formic, and acetic acids). Several additional LMW organic acids, as well as other LMW organic molecules, are also likely to be formed photochemically (Kieber et al. 1990; Wetzel et al. 1995; Corin et al. 1996; Moran and Zepp 1997). Therefore, the reported quantities of photochemically produced LMW organic substances are likely underestimates.

The production of LMW carboxylic acids was generally highest in spring with a lower photoreactivity potential during the summer season. These results support previously reported observations of an irradiation-induced stimulation of bacterial secondary growth in lake water collected during early summer, while no such effects could be observed later in the season (Geller 1986). Lindell et al. (1995) observed a strong increase in bacterial growth potential after exposing humic lake water to artificial UV radiation. However, a plateau in the bacterial growth response was reached after a prolonged exposure, with no further increase in growth potential. According to Wetzel et al. (1995), these combined findings may be explained by an initially high but rapidly diminishing photorelease of LMW organic substances, potentially involving a sequential, further photooxidation of formed LMW substances into inorganic forms. Indeed, photochemically produced oxalic acid can easily be oxidized further into DIC (Kulovaara and Backlund 1993; Bertilsson and Allard 1996; Bertilsson and Tranvik 1998). In the present study, oxalic acid generally comprised less than $5 \%$ of the total carbon retrieved in the analysed LMW carboxylic acids. The samples were exposed for $22 \pm 2 \mathrm{~h}$, a period that could be long enough for a complete oxidation of photochemically released oxalic acid (Bertilsson and Tranvik 1998). The detailed study of such a process was beyond the scope of the present study, but it should be acknowledged that such further photooxidation processes might influence measured photoproduction rates of LMW organic substances relative inorganic forms (Moran and Zepp 1997). If bacteria were present during the exposure, a fraction of such photo- labile LMW organic substances could be assimilated before being further photooxidized to DIC.

The analysed acids are readily available substrates for heterotrophic bacterial utilization in pelagic environments (Robinson et al. 1973; Wetzel et al. 1995; Bertilsson and Tranvik 1998), and a significant photochemical production of these compounds could positively influence bacterial activity and abundance. In contrast, the photochemical formation of DIC could represent a removal of potential substrates from the organic carbon pool, with an associated negative effect on bacterial growth. Thus, bacterial growth response to solar radiation might be a complex interaction between several concurrent photoreactions.

\section{Relative importance of spectral wavelength bands}

The relative effects of UV-B irradiation on photooxidation and photoproduction of LMW carboxylic acids varied between 25 and 50\% (Figs. 4 and 5). This production is considerable, taking into account the low total energy in UV-B compared with UV-A radiation. These results are consistent with the findings of Granéli et al. (1998), who reported that $30 \%$ of total UV-mediated DIC production could be related to UV-B in waters exposed to natural solar radiation. However, none of these calculations include the effects of PAR, which, together with UV-A, may account for more than $80 \%$ of the photochemical oxidation of DOC into DIC in lake water under natural sunlight (Granéli et al. 1998). Indeed, PAR alone may account for roughly twice the photochemical DIC production originating from UV-B irradiation. UV-B radiation was more important for photochemical DIC production in water from Lake Fiolen compared with Lake Skärshultsjön (average 43 and 26\%, respectively, of total production), which could be due to a higher proportion of relatively photorecalcitrant DOM in Lake Fiolen. Such DOM may need the more energy-rich UV-B photons to become photooxidized compared with the relatively "fresh" and thus photoreactive DOM in Lake Skärshultsjön, which may be photooxidized by the less energy-rich UV-A photons.

\section{Conclusions}

Our findings have several implications for the assessement of the importance of photochemical reactions occurring in lakes. We showed that the potential for complete photooxidation and photochemical carboxylic acid production varies seasonally, being highest in late winter and spring (cf. Figs. 4 and 5). We also showed that the carbon-specific photoreaction potential of DOC in a humic lake was higher compared with a clearwater lake. The systems differed in that the humic system had a considerably shorter retention time and a higher input of allochthonous organic material. We therefore suggest that the origin of DOC as well as the past light history are two important regulators of the potential of DOC to undergo photoreactions. Thus, solar radiation could be a significant regulator of the recalcitrance of DOC, and such an effect would be most pronounced in clear waters with long retention times and an associated extensive light treatment of DOC in situ.

\section{Acknowledgements}

Financial support from the Swedish Natural Science Re- 
search Council to H. Wilhelm Granéli (G-AA/GU 04969315 ) and to Stefan Bertilsson (G-AA/GU 03596-314 grants to Bert Allard) are gratefully acknowledged. Additional financial support was also given by the EC-WET project to Måns J. Lindell. Several people helped with sampling and analysis, among whom Alexandre Magno Anesio, Måns Denward, and Lars Tranvik are especially acknowledged. Dr. P.E.K. Symons and two anonymous referees had constructive comments on earlier versions of the manuscript. Dr. Tom Nielsen kindly helped us with spectral measurements in the laboratory.

\section{References}

Amon, R.M.W., and Benner, R. 1996. Bacterial utilisation of different size classes of dissolved organic matter. Limnol. Oceanogr. 41: 41-51.

Bengtsson, R., Karlberg, S., and Müller, C. 1965. Excursion guide to the Aneboda area. Lund University, Lund, Sweden. (In Swedish.)

Bertilsson, S., and Allard, B. 1996. Sequential photochemical and microbial degradation of refractory dissolved organic matter in a humic freshwater system. Arch. Hydrobiol. Adv. Limnol. 48: 133-141.

Bertilsson, S., and Tranvik, L.J. 1998. Photochemically produced carboxylic acids as substrates for frshwater bacterioplankton. Limnol. Oceanogr. 43: 885-895.

Chrost, R.H., and Faust, M.A. 1983. Organic carbon release by phytoplankton: its composition and utilization by bacterioplankton. J. Plankton Res. 4: 477-493.

Clair, T.A., and Sayer, B.G. 1997. Environmental variability in the reactivity of freshwater dissolved organic carbon to UV-B. Biogeochemistry, 36: 89-97.

Cole, J.J., Caraco, N.F., Kling, G.F., and Kratz, T.K. 1994. Carbon dioxide supersaturation in the surface waters of lakes. Science (Washington, D.C.), 265: 1568-1570.

Corin, N., Backlund, P., and Kulovaara, M. 1996. Degradation products formed during UV-irradiation of humic waters. Chemosphere, 33: $245-255$.

Curtis, P.J., and Schindler, D.W. 1997. Hydrologic control of dissolved organic matter in low-order Precambrian Shield lakes. Biogeochemistry, 36: 125-137.

del Giorgio, P.A., Bird, D.F., Prairie, Y.T., and Planas, D. 1996. Flow cytometric determination of bacterial abundance in lake plankton with the green nucleic acid stain SYTO 13. Limnol. Oceanogr. 41: 783-789.

Fenchel, T., and Blackburn, T.H. 1979. Bacteria and mineral cycling. Academic Press, London, U.K.

Geller, A. 1986. Comparison of mechanisms enhancing biodegradability of refractory lake water constituents. Limnol. Oceanogr. 31: 755-764.

Granéli, W., and Granéli, E. 1991. Automatic potentiometric determination of dissolved oxygen. Mar. Biol. 108: 341-348.

Granéli, W., Lindell, M.J., and Tranvik, L.J. 1996. Photooxidative production of dissolved inorganic carbon in lakes of different humic content. Limnol. Oceanogr. 41: 698-706.

Granéli, W., Lindell, M.J., de Faria, B.M., and Estevez, F. 1998. Photoproduction of dissolved inorganic carbon in temperate and tropical lakes - dependence of wavelength band and dissolved organic carbon concentration. Biogeochemistry, 43: 175-195.

Keil, R.G., and Kirchman, D.L. 1994. Abiotic transformation of la- bile protein to refractory protein in sea water. Mar. Chem. 45: 187-196.

Kieber, R.J., Zhou, X., and Mopper, K. 1990. Formation of carbonyl compounds from UV-induced photodegradation of humic substances in natural waters: fate of riverine carbon in the sea. Limnol. Oceanogr. 35: 1503-1515.

Kulovaara, M., and Backlund, P. 1993. Effects of simulated sunlight on aquatic humic matter. Vatten, 49: 100-103.

Lindell, M.J., and Rai, H. 1994. Photochemical oxygen consumption in humic waters. Arch. Hydrobiol. Beih. Ergeb. Limnol. 43: 145-155.

Lindell, M.J., Granéli, W., and Tranvik, L. 1995. Enhanced bacterial growth in response to photochemical transformation of dissolved organic matter. Limnol. Oceanogr. 40: 195-199.

Meili, M. 1992. Sources, concentrations and characteristics of organic matter in softwater lakes and streams of the Swedish forest region. Hydrobiologia, 29: 23-41.

Miles, C.J., and Brezonik, L. 1981. Oxygen consumption in humiccolored waters by a photochemical ferrous-ferric catalytic cycle. Environ. Sci. Technol. 15: 1089-1095.

Miller, W.L., and Zepp, R.G. 1995. Photochemical production of dissolved inorganic carbon from terrestrial organic matter: significance to the oceanic organic carbon cycle. Geophys. Res. Lett. 22: 417-420.

Moran, M.A., and Zepp, R.G. 1997. Role of photreactions in the formation of biologically labile compounds from dissolved organic matter. Limnol. Oceanogr. 42: 1307-1316.

Naganuma, T., Konish, S., Inoue, T., Nakane, T., and Sukizaki, S. 1996. Photodegradation or photoalteration? Microbial assay of the effect of UV-B on dissolved organic matter. Mar. Ecol. Prog. Ser. 135: 309-310.

Robinson, G.G.C., Hendzel, L.L., and Gillespie, D.C. 1973. A relationship between heterotrophic utilization of organic acids and bacterial populations in West Blue Lake, Manitoba. Limnol. Oceanogr. 18: 264-269.

Salonen, K., and Vähätalo, A. 1994. Photochemical mineralisation of dissolved organic matter in Lake Skjervatjern. Environ. Int. 20: $307-312$.

Schindler, D.W., Curtis, P.J., Bayley, S.E., Parker, B.R., Beaty, K.G., and Stainton, M.P. 1997. Climate-induced changes in the dissolved organic carbon budgets of boreal lakes. Biogeochemistry, 36: 9-28.

Scully, N.M., McQuenn, D.J., Lean, D.R.S., and Cooper, W.J. 1996. Hydrogen peroxide formation: the interaction of ultraviolet radiation and dissolved organic carbon in lake waters along a 43-75 $\mathrm{N}$ gradient. Limnol. Oceanogr. 41: 540-548.

SMHI. 1995. Väder och Vatten. Väderåret 1995. Swedish Meterologic and Hydrological Institute. CA Tryck AB Norrköping, Sweden. (In Swedish.)

SMHI. 1996. Väder och Vatten. Väderåret 1996. Swedish Meteorologic and Hydrological Institute. CA Tryck AB Norrköping, Sweden. (In Swedish.)

Thomas, D.N., and Lara, R.J. 1995. Photodegradation of algal derived dissolved organic carbon. Mar. Ecol. Prog. Ser. 116: 309-310.

Tranvik, L. 1990. Bacterioplankton growth on fractions of dissolved organic carbon of different molecular weights from humic and clear waters. Appl. Environ. Microbiol. 56: 1672-1677.

Valentine, R.L., and Zepp, R.G. 1993. Formation of carbon monoxide from the photodegradation of terrestrial dissolved organic carbon in natural waters. Environ. Sci. Technol. 27: 409-412.

Wetzel, R.G., Hatcher, P.G., and Bianchi, T.S. 1995. Natural photolysis by ultraviolet irradiance of recalcitrant dissolved organic matter to simple substrates for rapid bacterial metabolism. Limnol. Oceanogr. 40: $1369-1380$. 